\title{
Introduction: The Strange Case of the Second Redaction of Oresme's Questions on Meteorology
}

\author{
The redaction of Oresme's Questions on Meteorology that is partially edited in \\ this volume was until recently considered to be Oresme's only commentary on \\ Aristotle's Meteorology. ${ }^{1}$ However, recent investigations have revealed the exist- \\ ence of two other commentaries on this Aristotelian text that should also be \\ ascribed to Oresme: a literal commentary (Sententia) and a question comment- \\ ary (Questiones). ${ }^{2}$
}

1 As an example, Weijers's and Lohr's inventories mention only this redaction of Oresme's Questions on Meteorology: O. Weijers and M. Calma, Le travail intellectuel à la Faculté des arts de Paris: textes et maîtres (ca. 1200-1500). Répertoire des noms commençant par L-M-N-O, Turnhout 2005 (Studia Artistarum, 13), 175; Ch. Lohr, Latin Aristotle Commentaries, I.2. Medieval Authors M-Z, Florence 2010 (Corpus Philosophorum Medii Aevi. Subsidia, 18), 34-35.

2 Both texts are transmitted in a Parisian manuscript which bears the signature Darmstadt, Universitäts- und Landesbibliothek, Hs. 2197. The importance of this manuscript has been pointed out by Stefano Caroti in his introduction to the edition of Oresme's Questions on De generatione et corruptione: Nicolaus Oresme, Questiones super De generatione et corruptione, ed. S. Caroti, München 1996 (Veröffentlichungen der Kommission für die Herausgabe ungedruckter Texte aus der mittelalterlichen Geisteswelt, 20), $35^{*}-46^{*}$. The literal commentary is transmitted on ff. $100^{\mathrm{ra}}-123^{\text {ra }}$; the question commentary, on ff. $58^{\mathrm{ra}-82^{\mathrm{rb}}}$ and $125^{\mathrm{ra}}-127^{\mathrm{rb}}$. Both texts are ascribed to Nicole Oresme in the manuscript: "Expliciunt questiones primi Metheororum compilate ante magistrum Nicholaum de Oresme Normannum Deo gratias. Incipiunt questiones secundi eiusdem ab eodem" (f. 81 ${ }^{\mathrm{rb}}$ ); "Explicit sententia primi Metheororum reportata ante magistrum Nicholaum Oresme nationis Normannorum. Incipit sententia secundi eiusdem reportata ab eodem" (f. $106^{\mathrm{ra}}$ ). My research enabled me to identify five other copies of this redaction of Oresme's Questions on Meteorology: München, Bayerische Staatsbibliothek, Clm 4375, ff. $19^{\text {ra }}-46^{\text {rb }}$; Kraków, Biblioteka Jagiellońska, cod. 753 , ff. $51^{\text {ra }}-83^{\text {vb}}$; cod. 635 , pp. $194^{\mathrm{a}}-209^{\mathrm{a}}$ (only questions I.19-31); $\operatorname{cod} .686$, ff. $11 \mathrm{O}^{\mathrm{vb}}-12 \mathrm{O}^{\text {ra }}$ (only questions I.19-31 and II.1-6); cod. 686, ff. $81^{\text {ra }}-97^{\text {va }}$ (only questions I.3 and I.12-32). For more information on this redaction of Oresme's commentary, see A. Panzica, "Une nouvelle rédaction des Questions sur les Météorologiques de Nicole Oresme", Bulletin de philosophie médiévale 57 (2015), 257264; Ead., "Nicole Oresme à la Faculté des Arts de Paris: les Questions sur les Météorologiques", Archives d'histoire doctrinale et littéraire du Moyen Âge 84 (2017), 7-89, esp. 13-21; Ead., "Albert of Saxony's Questions on Meteorology: Introduction, Study of the Manuscript Tradition, and Edition of Book I-II.2", Archives d'histoire doctrinale et littéraire du Moyen Âge 86 (2019), 231356, esp. 232-239; Ead., "L' hypothèse de la cessation des mouvements célestes au XIV ${ }^{\mathrm{e}}$ siècle: Nicole Oresme, Jean Buridan et Albert de Saxe", Vivarium 56 (2018), 83-125; Ead., De la Lune à la Terre: les débats sur le premier livre des Météorologiques d'Aristote au Moyen Âge latin (XII $X V^{e}$ siècles), forthcoming. An edition of this commentary will soon be published in the Brill series Medieval and Early Modern Philosophy and Science. 
There is textual and doctrinal evidence that these two newly discovered texts predate the question commentary on Aristotle's Meteorology by Oresme that was previously known in the literature. Both texts are transmitted in a Parisian codex which dates back to $1346 .{ }^{3}$ This important manuscript, which was copied by two students writing under Oresme's direct supervision, ${ }^{4}$ is the oldest identified witness of an Oresmian text. A doctrinal comparison of the two redactions of Oresme's Questions on Meteorology suggests that the newly discovered commentary is the earlier of the two: in this text, Oresme's arguments are rich and profound, but sometimes inconsistent, and not as clearly formulated as in the previously known set of questions. Moreover, at some points, it seems that in the first redaction of his Questions on Meteorology, Oresme is searching for his own philosophical path, exploring solutions that he would subsequently abandon. For instance, he defends the astrological theses that astral influence acts not only on primary, but also on secondary qualities (question I.3); that planetary conjunctions affect social and political events (question I.5); and that the observation of the stars allows us to predict atmospheric phenomena (question II.5). By contrast, in the second redaction of his Questions on Meteorology, which was discovered first, Oresme tends to belittle the importance of celestial causes and to explain natural phenomena mainly on the basis of sublunary principles - an attitude that he maintains and further develops in his later writings. ${ }^{5}$ In light of these considerations, I shall refer to the commentary edited in this volume as the ultima lectura, and to the recently discovered one as the prima lectura. ${ }^{6}$

There is neither internal nor external evidence that allows us to establish a precise dating for the second redaction of Oresme's Questions on Meteorology. Although the oldest manuscripts transmitting this text date back to the second half of the 1360 s, we can reasonably suppose that Oresme prepared this commentary in the context of his teaching career at the Parisian Faculty of Arts. This

3 This date appears in the colophon at f. $192^{\mathrm{vb}}$ : "Expliciunt questiones super librum De anima reportate ante magistrum Johannem de Wesalia in vico straminum Parisius per manus Johannis Margan de Yvia, anno domini $\mathrm{m}$ ccc $46^{\circ}$.

4 The students in question are Iohannes Margan de Yvia and Henricus de Danderiche, both native of the diocese of Liège. For more information on these students, see Nicole Oresme, Questiones super de generatione et corruptione, ed. S. Caroti, $46^{*}$, as well as the introduction to the newly discovered redaction of Oresme's Questions on Meteorology, in this series (forthcoming).

5 Oresme's differing positions on astral influence in the two redactions of his Questions on Meteorology are addressed in Panzica, De la Lune à la Terre.

6 In some of the publications cited in footnote 2, I used the labels redactio antiqua (for the prima lectura) and redactio nova (for the ultima lectura). 
period extends from the beginning of the $134 \mathrm{Os}^{7}$ to the first half of the 135 os. The date commonly assumed to mark the end of Oresme's teaching activity at the Arts Faculty is 1356 , the year in which he became Great Master of Theology at the College of Navarre. ${ }^{8}$ Oresme's self-references provide us with some information about the relative chronology of the second redaction of his Questions on Meteorology. ${ }^{9}$ At the end of question I.8, Oresme refers to his commentary on Aristotle's Physics. ${ }^{10}$ According to the modern editors of his Questions on the Physics, the terminus ante quem of this text is 1347 , as this was the year in which a theory of accidents that Oresme used extensively in his commentary was officially condemned. ${ }^{11}$ Question I.8 also contains another self-reference, in which Oresme mentions the theory of impetus discussed in the first book of his commentary on Aristotle's De celo..$^{12}$ Oresme's Questions on De celo has been edited

7 Courtenay has shown that Oresme was already Master of Arts by 1342: W.J. Courtenay, "The Early Career of Nicole Oresme", Isis 91 (2000), 542-548. For biographical information about Oresme, see E. Grant's edition of Oresme's De proportionibus proportionum and Ad pauca respicientes, Madison 1966 (University of Wisconsin Publications in Medieval Science), 3-10; S.M. Babbitt, Oresme's Livre de Politiques and the France of Charles V, Philadelphia 1985 (Transactions of the American Philosophical Society, 75), 1-12; F. Neveux, "Nicole Oresme et le clergé normand du XIve siècle", in J. Quillet (ed.), Autour de Nicole Oresme. Actes du colloque Oresme organisé à l'Université de Paris XII, Paris 1990 (Bibliothèque d' histoire de la philosophie), 9-36; M. Lejbowicz, "Nicole Oresme dans la lumière de l'urbanité", in P.J.J.M. Bakker, E. Faye, and C. Grellard (eds.), Chemins de la pensée médiévale: Études offertes à Zénon Kaluza, Turnhout 2002 (Textes et Etudes du Moyen Âge, 20), 675-708; Id., "Nicole Oresme, spectateur engagé", in J. Celeyrette and C. Grellard (eds.), Nicole Oresme philosophe, Turnhout 2014 (Studia Artistarum, 39), 21-61.

8 On this institution, founded by the King within the University of Paris, see N. Gorochov, Le Collège de Navarre: de sa fondation (1305) au début du Xvème siècle (1418): histoire de l'institution, de sa vie intellectuelle et de son recrutement, Paris 1997 (Études d'histoire médiévale, 1) and W.J. Courtenay, "The University of Paris at the Time of Jean Buridan and Nicole Oresme", Vivarium 42 (2004), 3-17, esp. 12-14.

9 On the relative chronology of Oresme's commentaries used for teaching at the Arts Faculty see J. Celeyrette, "Les Questions sur la Physique dans l'œuvre de Nicole Oresme”, in Celeyrette and Grellard (eds.), Nicole Oresme philosophe, 63-82, esp. 64-66 and Panzica, Nicole Oresme à la Faculté des Arts de Paris, 27-33.

10 This reference appears in the answer to the fifth argument contra: "dico quod motus calefacit accipiendo 'motum' pro 'mobili taliter se habere'; sed utrum mobile sic se habere sit ipsum mobile, vel aliud, vel que res sit, dictum est in libro Physicorum". Oresme deals with this problem in questions III.2-III.7 of his commentary on the Physics.

11 S. Caroti, J. Celeyrette, S. Kirschner, and E. Mazet (eds.), Nicole Oresme. Questiones super Physicam (Books I-VII), Leiden/Boston 2013, XXv. See also S. Caroti, "Modi rerum and Materialism: a Note on a Quotation of a Condemned Articulus in Some FourteenthCentury Parisian De anima commentaries", Traditio 55 (2000), 211-234.

12 This reference appears in the answer to the third argument contra: "concedo quod lapis in descendendo calefit. Et quando dicebatur: 'igitur leve fieret', concedo—-hoc est, fit minus 
by Kren, who considers it to be a very early work to be dated to the beginning of Oresme's teaching at the Arts Faculty — that is to say, according to Kren, to the second half of the 1340s. ${ }^{13}$ In the text edited by Kren, Oresme refers to his Questions on the Physics and to his Questions on Meteorology. The fact that, in the second redaction of his Questions on Meteorology, he refers to the Questions on De celo can be explained in two different ways: either he is referring to the first redaction of his Questions on Meteorology in the Questions on De celo, or he is pointing to another version of his Questions on De celo in the second redaction of his Questions on Meteorology. Both solutions are possible. If we look more closely at the self-references in the Questions on De celo, we find that parallel passages can be found in both redactions of Oresme's Questions on Meteoro$\operatorname{logy}$, yet these topics are dealt in more detail in the first redaction. ${ }^{14}$ But it is

gravis. Et cum dicebatur: 'igitur in fine moveretur tardius quam in principio', concedo nisi aliud obesset; sed modo in eius descensu acquirit quemdam impetum de quo dicebatur super primum Celi".

13 C. Kren, The Questiones super de Celo of Nicole Oresme, unpublished Ph.D. Dissertation, University of Wisconsin 1965 , X-XII.

14 The self-references at issue occur in question II.13, Utrum tota terra semper quiescat, ed. Kren 681 144-147: "respondetur quod non oportet quia sicud dictum est super librum Meteororum, motus calefacit propter confricationem corporum que non est in proposito quia aer usque prope speram ignis movetur hoc modo". A corresponding passage can be found in question I.7 (Utrum motus localis sit causa caloris) of the first redaction of Oresme's Questions on Meteorology: "Secunda conclusio est quod motus turbidus calefacit. Patet, quia ex tali motu partes distrahuntur et rarefiunt, per primam suppositionem, et ad rarefactionem sequitur calefactio, per secundam [...]. Ultima conclusio: quod motus tranquillus calefacit, non tamen solus, sed quia ex confricatione cum exteriori continente fit motus turbidus, ex quo sequitur distractio, deinde rarefactio et calefactio consequentes. Patet ex exemplo de sagitta proiecta, et etiam de ferro confricato lapidi". Oresme addresses the same topic in question I.8 (Utrum motus celi sit causa calefactionis ignis in sua spera et etiam aeris superioris) of the second redaction of his commentary, but with greater concision: "Sic ergo motus qui fit cum confricatione est causa caloris. Unde ymaginandum est quod ex tali confricatione fit quedam rarefactio et quedam partium distractio, quam consequitur caliditas". The second reference to the commentary on Meteorology contained in the Questions on De celo is the following: "Ad rationes in oppositum ad primam, sicud est de igne, et cetera, dico quod non est simile quia ignis est propinquior celo quam terra et propter hoc movetur ut patuit primo Meteororum" (II.13, Kren, 695 $\left.{ }^{266-269}\right)$. Oresme is probably referring to question I.4 (Utrum aliquis motus localis in istis inferioribus sit effective a celo) of the first redaction of his Questions on Meteorology: "Quinto movet celum inferiora mediante solu motu locali; sic dicitur quod movet speram ignis vel ignem in spera, quia propter nimiam velocitatem trahit secum ignem tali motu". The second redaction of his commentary does not contain any specific question devoted to the motion of the sphere of fire, but this topic is briefly addressed in question I.8 (Utrum motus celi sit causa calefactionis ignis in sua spera et etiam aeris superioris): "Secunda conclusio: ignis sic movetur, videlicet circulariter una cum celo, per virtutem sibi impressam a celo, eo modo 
equally possible that, in the second redaction of his Questions on Meteorology, Oresme is referring to a different redaction of his Questions on De celo than the one edited by Kren. In fact, while Oresme refers to the first book of his Questions on De celo for a discussion of impetus theory, in the text edited by Kren this topic is discussed in the second book. ${ }^{15}$ This might be an additional argument for ascribing to Oresme the anonymous set of questions on Aristotle's De celo transmitted in the manuscript München, Bayerische Staatsbibliothek, Clm 4375 , ff. $47^{\text {ra }}-76^{\text {ra }}$, whose Oresmian paternity was suggested by Kirschner. ${ }^{16}$ In this commentary, impetus theory is discussed in the first book. ${ }^{17}$

The second redaction of Oresme's Questions on Meteorology is transmitted in nineteen manuscripts, one of which was identified during the preparation of this edition (Poznań, Archivum Archidiecezjalne, Cms 53, ff. $1^{r}-95^{v}$ ). Almost all of these manuscripts originated in Central and Eastern Europe, particularly in Prague. This situation has precise historical reasons, since Oresme's commentary was used at Prague University for teaching of Aristotle's Meteorology. Oresme's Questions had a great impact on the medieval reception of this Aristotelian text, starting with other Parisian masters of the fourteenth century, namely Albert of Saxony and Themo Iudeus, who based their commentaries on that of Oresme. ${ }^{18}$ While Albert's Questions had only a limited circulation, ${ }^{19}$

quo ferrum movetur insequendo magnetem. Patet, quia ex quo non movetur motu raptus, sicut dicebat prima conclusio, non videtur esse alius modus dicendi nisi dicatur quod sic movetur per virtutem sibi impressam a celo".

15 Nicole Oresme, Questions on De celo II.7 (Utrum motus naturalis sit velocior in fine quam in principio), ed. Kren, 559 343-346: "Quarto modo quod est ad propositum, ex velocitatione motus per quam acquiritur quedam habilitas vel impetus et quedam fortificatio accidentalis ad velocius movendum".

16 S. Kirschner, "Eine weitere Fassung eines lateinischen 'De caelo-Kommentars' von Nicolaus Oresme?", in B. Fritscher, G. Brey (eds.), Cosmographica et Geographica. Festschrift für Heribert M. Nobis zum 70. Geburtstag, 1, München 1994 (Algorismus 13), 209-222.

17 München, Bayerische Staatsbibliothek, Clm 4375, I.22 (Utrum motus naturalis sit velocior in fine quam in principio), f. 61 $1^{\text {va: }}$ "omne motum naturaliter ab intrinseco in velocitando motum acquirit fortitudinem et habilitatem coadiuvantem ipsum motum, quod potest dici impetus, vel inclinatio accidentalis".

18 For the list of questions discussed in Albert's and Themo's commentaries, see respectively Panzica, "Nicole Oresme à la Faculté des Arts de Paris", 57-63 and 64-72. For some examples of the dependence of Albert of Saxony's Questions on Meteorology on that of Oresme's, see Panzica, “Albert of Saxony's Questions on Meteorology", 232-241. This article contains an edition of books I-II.2 from Albert's commentary (268-356): a comparison between this text and the corresponding part of Oresme's commentary, edited in the present volume, clearly shows that Albert relies on Oresme.

19 Only two complete manuscripts of Albert of Saxony's Questions on Meteorology are known: Erfurt, Universitäts- und Forschungsbibliothek, Dep. Erf., CA $4^{\circ} 299$, ff. $53^{\mathrm{r}}-103^{\mathrm{v}}$ 
Themo's Questions was printed several times between the end of the fifteenth and the beginning of the sixteenth century. ${ }^{20}$ Probably through the intermediary of Themo, the influence of Oresme's commentary spread to England and Italy: many of Oresme's theses were adopted by the Italian master Blasius of Parma $^{21}$ and by an anonymous Scotist master at the end of the fourteenth century. Ascribed to Duns Scotus, this anonymous question commentary on Aristotle's Meteorology was printed by Wadding in Scotus's Opera omnia in the

and Berlin, Staatsbibliothek-Preußischer Kulturbesitz, lat. fol. 387, ff. $63^{\mathrm{r}}-102^{\mathrm{v}}$. Two Krakow manuscripts contain a compilation consisting of questions I.19-31 from the first redaction of Oresme's commentary on Meteorology and questions I.1-I.14, II.7-17, as well as books III and IV, from Albert's commentary: Kraków, Biblioteka Jagiellońska, BJ 635, pp. $177-236$ and 686 , ff. $101^{\text {ra }}-134^{\text {va }}$. A Parisian manuscript also contains a compilation from Albert (II.11-III.9) and Oresme (in this case, the second redaction of Oresme's commentary: I.1-II.1O): Paris, Bibliothèque Nationale de France, lat. 15156, ff. $226^{\mathrm{r}}-288^{\mathrm{v}}$. Two other manuscripts contain fragments from the first question of Albert's commentary: Wien, Österreichische Nationalbibliothek, Cod. 5453, f. 48 ${ }^{\mathrm{vb}}$ and Kraków, Biblioteka Jagiellońska, cod. 751, f. $2^{\mathrm{r}-\mathrm{v}}$. On these manuscripts see Panzica, "Albert of Saxony's Questions on Meteorology", 248-266.

20 Themo's Questions on Meteorology is transmitted in a considerable number of manuscripts, the majority of which are of Italian origin: Città del Vaticano, Biblioteca Apostolica Vaticana, Vat. lat. 2177, ff. $1^{\mathrm{r}}-{ }^{2} 2^{\mathrm{v}}$; Padova, Seminario vescovile, cod. 24, ff. $\mathrm{1}^{\mathrm{r}}-5^{\mathrm{O}}$; Ferrara, Biblioteca comunale Ariostea, Ms. Classe II, n. 38o, ff. $\mathrm{r}^{\mathrm{r}}-6 \mathrm{o}^{\mathrm{v}}$; München, Bayerische Staats-

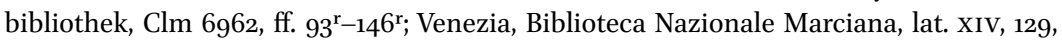
ff. $77^{\mathrm{r}}-122^{\mathrm{v}}$ (formerly: Venezia, Biblioteca del Monastero di S. Michele, 136); Paris, Bibliothèque Nationale de France, lat. $6547, \mathrm{ff}^{\mathrm{r}} \mathrm{1}^{\mathrm{r}}-33^{\mathrm{r}}$ (incomplete copy). The first edition was printed in Pavia around 1480; other editions were printed in Venice by Ottavianus Scotus in 1496, 1507, 1515, 1522 (along with Gaetanus of Thiene's commentary on Meteorology). Georges Lockert printed Themo's Questions in Paris in 1516 and 1518 (along with other commentaries on Aristotle by Parisian masters of the fourteenth century: Albert of Saxony's Questions on Physics and on De celo; John Buridan's Questions on De anima and on the Parva naturalia).

21 Blasius of Parma's Questions on Meteorology is transmitted in five manuscripts: Città del Vaticano, Biblioteca Apostolica Vaticana, Chigi O IV 41, ff. $59^{\mathrm{r}}-105^{\mathrm{r}}$; Città del Vaticano, Biblioteca Apostolica Vaticana, Vat. lat. 216o, ff. $62^{\mathrm{r}}-138^{\mathrm{v}}$; Firenze, Biblioteca Medicea Laurenziana, Ashburnham 185, ff. $1^{\mathrm{r}}-59^{\mathrm{v}}$; Chicago, University Library, ms. 10 , ff. $1^{\mathrm{ra}}-37^{\mathrm{va}}$ (incomplete copy); Città del Vaticano, Biblioteca Apostolica Vaticana, Vat. lat. 4082, ff. $82^{\mathrm{vb}}-85^{\mathrm{va}}$ (only qq. I.8-9). For the recent identification of the last witness, see A. Panzica, "Les Questions sur les Météorologiques du manuscrit Vat. Lat. 4082: Blaise de Parme, Nicole Oresme et l'Inter omnes impressiones", Bulletin de philosophie médiévale 61 (2019), 153-182. At question III.6 of his commentary, Blasius refers explicitely to Oresme's theory of the rainbow: "Prime difficultati respondet Nicholaus Horen et facit hanc ymaginationem ut quod in apparitione iridis sunt ymaginandi plures ordines guttarum aque, quarum alique sunt propinquiores oculo", ms. Città del Vaticano, Biblioteca Apostolica Vaticana, Vat. lat. 216o, f. $123^{\text {va }}$. 
seventeenth century. ${ }^{22}$ In Central and Eastern Europe, the influence of the second redaction of Oresme's Questions on Meteorology was direct and profound. This is particularly evident in the question commentaries on Aristotle's Meteorology by three Polish masters who taught in the 1420s, namely Benedictus Hesse de Cracovia, Paul of Worczyn and Peter of Sienno, who rely heavily on Oresme's text and explicitly quote it. ${ }^{23}$

Rediscovered at the end of the nineteenth century, the second redaction of Oresme's Questions on Meteorology attracted the attention of the historian of science Alexander Birkenmajer, who provided a first list of manuscripts and studied their interrelations. ${ }^{24}$ Birkenmajer also pointed out a puzzling fact about this set of questions, namely that the greater part of the third book of Oresme's commentary is almost identical to the corresponding book in Themo Iudeus' Questions. In this portion of the text, Oresme's questions reveal many philosophical and textual inconsistencies. For example, they contain theses rejected elsewhere by Oresme and internal references that cannot be found in Oresme's text, but only in Themo's. Since all of the manuscripts to which he had access stem from Central and Eastern Europe, Birkenmajer concluded that the form of Oresme's commentary as transmitted cannot be the original one, but rather shows evidence of a contamination from Oresme's and Themo's Questions. The origin of the oldest manuscripts suggested that the compilation was made at Prague University. The methods used to teach Aristotle's philosophy at the Prague Arts Faculty make this hypothesis very likely: as documented by the Statutes, bachelors and masters at this university used to base their lectures on commentaries by famous masters from Paris and Oxford. According to this hypothesis, Oresme's text was therefore reworked in Prague for use in lectures and, in the process, contaminated with Themo's Questions. ${ }^{25}$

Birkenmajer's reconstruction was rejected by McCluskey, who edited the questions concerning light and vision from the third book of the commentary

22 Iohannes Duns Scotus, Opera omnia, ed. L. Wadding, Lyon 1639, reprint Hildesheim 1968 (12 vols.), 3: 1-125. On this text see L. Petrescu, "The Threefold Object of the Scientific Knowledge. Pseudo-Scotus and the Literature on the Meteorologica in Fourteenth-century Paris", Franciscan Studies 72/1 (2014), 465-502 and Panzica, De la Lune à la Terre.

23 See A. Panzica, "Commenter les Météorologiques à l'Université de Cracovie: de l' assimilation des modèles parisiens à la naissance d'une tradition polonaise", Recherches de Théologie et Philosophie Médiévales 87/1 (2020), 77-166, esp. 108-140, and Panzica, De la Lune à la Terre.

24 A. Birkenmajer, Études d'histoire des sciences en Pologne, choix d' articles par J.B. Korolec, A.M. Birkenmajer, textes polonais trad. par C. Brendel [et al.], revus par J. Wolf, Wrocław/Warsaw/Krakow 1972 (Studia Copernicana, 4), 178-239.

25 Birkenmajer, Études d'histoire des sciences en Pologne, 181-198. 
ascribed to Oresme. ${ }^{26}$ According to McCluskey, it is not necessary to postulate the intervention of a third master in order to explain the current form of Oresme's commentary: McCluskey suggests that while preparing his lectures on Aristotle's Meteorology, Oresme himself took long passages from Themo's Questions without fully harmonising the two texts. ${ }^{27}$ Interestingly, McCluskey argues that if a Prague master had compiled this set of questions on Aristotle's Meteorology from two different sources, he would have made his lectures consistent, which is not the case. ${ }^{28}$ One wonders why McCluskey refuses to accept that Oresme himself might also have been concerned about consistency. As I have shown elsewhere, ${ }^{29}$ and as I will argue in more detail in the preface to the edition of the third book, I consider McCluskey's explanation to be unsatisfactory.

It is clear that the solution to this puzzle could only come from a Parisian copy of Oresme's text. Such a copy was discovered by Thorndike in 1954 in the manuscript Paris, Bibliothèque Nationale de France, lat. $15156 .{ }^{30}$ Unfortunately, this manuscript cannot help us to evaluate the authenticity of the third book of Oresme's commentary that is transmitted in the Central European family of manuscripts, since the text stops abruptly at question II.10, breaking off in the middle of a sentence. After a blank leaf, the text restarts with question II.11 of Albert of Saxony's Questions on Meteorology. Yet this witness is not without importance for the reconstruction of the tradition of Oresme's Questions. While Birkenmajer and McCluskey focused on the third book, I collated the whole of the first and part of the second book transmitted in the Parisian manuscript with the other witnesses. As I will prove later in more detail, this comparison reveals many important differences between the Parisian manuscript and the other copies of Oresme's Questions. These differences, which are subtler than in the third book, reveal, on the one hand, the existence of two different traditions of Oresme's text and, on the other, the superiority of the Parisian tradition.

26 S.C. McCluskey, Nicole Oresme on Light, Color, and the Rainbow: an Edition and Translation, with Introduction and Critical Notes, of Part of Book III of his "Questiones super IV libros Meteororum", unpublished Ph.D. dissertation, University of Wisconsin 1974.

27 McCluskey, Nicole Oresme on Light, Color, and the Rainbow, 30-63.

28 McCluskey, Nicole Oresme on Light, Color, and the Rainbow, 61-62, fn. 51 .

29 Panzica, "Nicole Oresme à la Faculté des Arts de Paris", 12; Ead., "Albert of Saxony's Questions on Meteorology: Introduction, Study of the Manuscript Tradition and Edition of Book I-II.2", Archives d'histoire doctrinale et littéraire du Moyen Âge 86 (2019), 231-356, esp. 231-241.

3o L. Thorndike, "Oresme and Fourteenth Century Commentaries on the Meteorologica", Isis 45 (1954), 145-152. 
The particular situation of the manuscript tradition of Oresme's commentary makes necessary the adoption of different editorial principles for the reconstruction of the text. In light of the differences between the Parisian manuscript and the Central European copies, I refrained from producing a composite text that switches from the extant part of the Parisian manuscript to the other copies. Rather, I deemed it reasonable to produce an edition of Oresme's commentary based on the Parisian manuscript first: this edition, which adopts the variants of the Central European family only when the Parisian witness is faulty, covers the portion of the text transmitted in the Parisian manuscript, i.e. the first book and the first ten questions of the second book. The rest of the text will be presented in a separate edition following different editorial principles.

In so doing, my intention is not to avoid addressing the problem of the authenticity of the third book. On the contrary, I am convinced that this partial edition will provide us with important evidence that will facilitate the evaluation of the problems posed by the third book in the broader context of Oresme's commentary. Other important data for the solution of this enigma will be provided by the edition of the first redaction of Oresme's Questions on Meteorology, on which I am working in parallel. A comparison of the list of questions from the third book discussed in the two redactions of Oresme's Questions reveals an interesting fact: most of the questions found in the second redaction that contain inconsistencies and that were thought to be spurious by Birkenmajer are missing from the first redaction. I am confident that a parallel edition and study of the two redactions will help us understand the strange case of contamination in the second redaction of Oresme's Questions on Meteorology. 